No2/2009

ENVIRONMENTAL LAW NETWORK INTERNATIONAL

RÉSEAU INTERNATIONAL

DE DROIT DE L'ENVIRONNEMENT

INTERNATIONALES

NETZWERK UMWELTRECHT

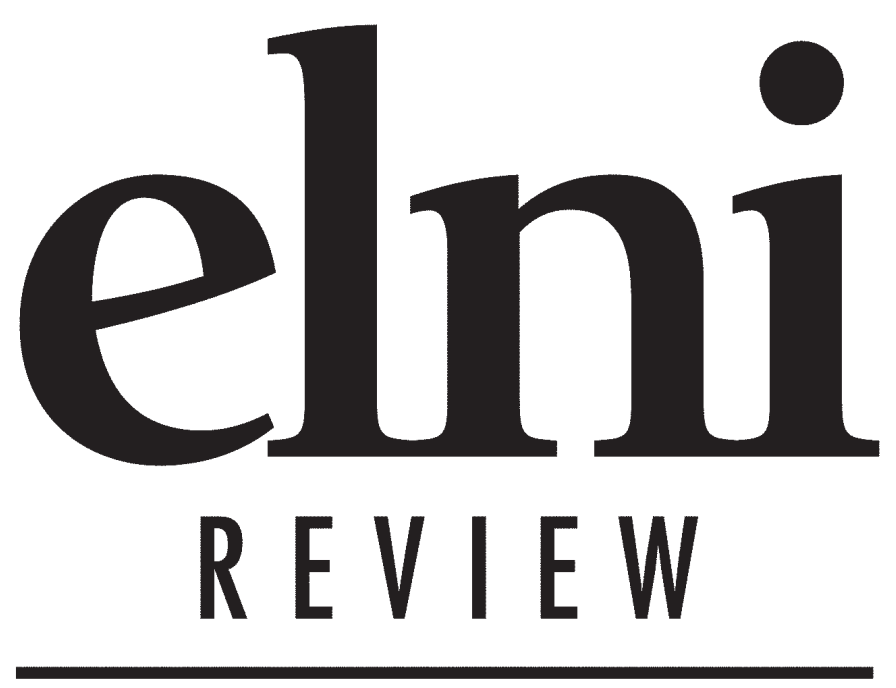

EU Enforcement Policy of Community Environmental law as presented in the Commission Communication on implementing European Community Environmental law Marta Ballesteros

The direct effect of the Aarhus Convention as seen by the French 'Conseil d'Etat'

Julien Bétaille

Practical application of Article 9 of the Aarhus Convention in EU countries: Some comparative remarks

Pavel Černý

Environmental Inspections at the EU:

The imperative to move forward

Ana Barreira

Current discussions on the proposal for an Industrial Emissions Directive: Stronger role for Best Available Techniques?

Christian Schaible

Aberthaw Power Station: An IPPC case study Lesley James

Why patents are crucial for the access of developing countries to Environmentally Sound Technologies

Michael Benske

Conference Reports 


\section{CONTENTS}

Editorial

Conference on Environmental Law and Policy in the European Union:

The Legacy of the Treaty of Amsterdam

\section{Articles with focus on the Aarhus Convention}

EU Enforcement Policy of Community Environmental law as presented in the Commission Communication on implementing European Community Environmental law

Marta Ballesteros

The direct effect of the Aarhus Convention as seen by the French 'Conseil d'Etat' Julien Bétaille

Practical application of Article 9 of the Aarhus Convention in EU countries: Some comparative remarks 74 Pavel Černý

Environmental Inspections at the EU: The imperative to move forward 79 Ana Barreira

\section{Articles with focus on the Industrial Emissions Directive and other topics}

Current discussions on the proposal for an Industrial Emissions Directive:

Stronger role for Best Available Techniques?

Christian Schaible

Aberthaw Power Station: An IPPC case study

Lesley James

Why patents are crucial for the access of developing countries to Environmentally Sound Technologies ...

Michael Benske

\section{Conference reports}

elni forum 2009 - The EU Directive on Industrial Emissions and its implementation in national law key issues and practical experiences, 14th May 2009 in Brussels, Belgium.

Nicola Below

Report of the Congress

"European Environmental Law in Belgium and the Netherlands" of 15th May 2009 95

Marie-Catharine van Engelen

\section{Latest News}

Access to Justice in Slovakian Environmental Impact Assessment proceedings: NGOs strengthened 82

Report from the European Commission on the application and effectiveness of the EIA Directive 82

Germany fails again to codify its fragmented environmental law 97

Special edition of elni 98

elni Conference 2010 on the Industrial Emissions Directive (IED/ current IPPC Directive) 98

Imprint 99

Authors of this issue 99

elni Membership 


\section{Editorial}

It has been nearly ten years now since the Aarhus Convention entered into force and imposed on parties and public administrations obligations regarding access to information, public participation in decision-making and access to justice. Since then, practitioners have gained diverse experiences on the practical application of the three pillars' provisions, and their implementation into national laws and related issues, e.g. enforcement. This issue of the elni Review includes valuable insights into this matter.

Special focus in this issue is placed on the currently discussed revision of the IPPC Directive takes a special place in this issue of the elni Review. This topic will also be continued in the next issue of the journal to reflect the ongoing discussion. As previously announced, elni is planning an elni Conference (see page 46 of this journal), a major event by the end of 2010, on the Industrial Emissions Directive. Therefore, you are invited to send us your contribution for the elni Review and, if you are willing to discuss it with others, you are naturally welcome to submit a proposal for the event, too. Soon, there will be an official call on our webpage (www.elni.org) providing further information on the conference.

This issue 2/2009 of the elni Review offers the following contributions:

In her article on the Conference "EU Enforcement Policy of Community Environmental law as presented in the Commission Communication on implementing European Community Environmental law" which took place on 8 July 2009 in Brussels, Marta Ballesteros discusses the implementation of European Community Environmental Law enforcement and its interaction with the Aarhus Convention and other European Laws.

"The direct effect of the Aarhus Convention as seen by the French 'Conseil d'Etat'” is the subject of the article by Julien Bétaille. His article provides detailed insights on the implementation and practical application of the Aarhus Convention in France.

"Practical application of Article 9 of the Aarhus Convention in EU countries: Some comparative remarks" by Pavel Černý discusses several specific topics from this field which can be considered crucial to legal protection of the environment in practice. The article also addresses the contributions and discussions presented at the „International conference on the implementation of the Aarhus Convention in practice".

The article "Environmental Inspections at the EU: The imperative to move forward" by Ana Barreira reflects the point of view of the EEB on compliance and enforcement of European Environmental Law.

Further Christian Schaible addresses the EEB's position on the revision of the IPPC Directive in his article "Current discussions on the proposal for an Industrial Emis- sions Directive: Stronger role for Best Available Techniques?”.

National specifics of the IPPC Directive in practice are shown from a British point of view by Lesley James. She comments on the "Aberthaw Power Station: An IPPC case study”.

"Why patents are crucial for the access of developing countries to Environmentally Sound Technologies" is explained by Michael Benske.

This issue of elni Review also provides two conference reports:

Nicola Below reports on the elni forum 2009 "The Directive on Industrial Emissions and its implementation in national law - key issues and practical experiences”, which took place at CEDRE in Brussels on $14^{\text {th }}$ May 2009. The contribution by Marie-Catharine van Engelen reports on the congress "European Environmental Law in Belgium and the Netherlands", which took place in Rotterdam on $15^{\text {th }}$ May 2009.

Moreover, this edition of elni Review covers some interesting news on the German failure to codify its fragmented environmental law, a special edition of elni Review, which will be published next year, the elni Conference 2010, recent EIA developments, and positive developments in Slovakian access to justice.

The next issue of the elni review will not have an overarching focus. Contributions on the IED/IPPC revision process are nevertheless very welcome. Please send contributions on this topic as well as other interesting articles to the editors by mid-January 2009.

Nicolas Below/Martin Führ

October 2009

Conference on Environmental Law and Policy in the European Union

on Thursday $19^{\text {th }}$ of November 2009 at the University of Amsterdam, The Netherlands

\section{"Environmental Law and Policy in the European Union: The Legacy of the Treaty of Amsterdam"}

On the occasion of the inaugural lecture of Professor Marc Pallemaerts on 20 November 2009, the Centre for Environmental Law is organising a conference.

Please confirm your participation under: http://www.jur.uva.nl/cel 


\title{
Practical application of Article 9 of the Aarhus Convention in EU countries: Some comparative remarks
}

\author{
Pavel Černý
}

\section{Introduction}

The Aarhus Convention" (hereinafter also called "the Convention") is a unique international legal instrument, which combines the subject of environmental protection with human rights as well as with the responsibilities of public institutions and also individuals and their associations towards the environment.

Application of the Convention in practice of its parties (including the European Communities) has been reflected recently by several representative studies. ${ }^{2}$ In spite of their partial differences, these studies come to similar conclusions with regard to the chief insufficiencies in implementation of requirements concerning access to justice in environmental matters according to Art. 9 of the Convention.

This article discusses several specific topics from this field, which can be considered crucial for legal protection of the environment in practice. More concretely:

- definition of terms for access to justice by individual members of public ("standing conditions")

- scope of the court review of act and omissions, related to the environment

- effectiveness of a court review, particularly its timeliness.

Next to the above mentioned studies, the article also refers to the contributions and discussions presented at the ,International conference on the implementation of the Aarhus Convention in practice" (hereinafter "the Conference"), which was organised in April 2009 in Brno, the Czech Republic, within the scope of the Czech EU presidency. ${ }^{3}$ A few more general but related aspects are touched upon, namely the position of the Convention in the legal system of its parties and its relation to the EC law.

The article is based namely on the outcomes of the projects concerning the NGO experience with using the Aarhus Convention in practice, sponsored by In-

1 Convention on Access to Information, Public Participation in Decisionmaking and Access to Justice in Environmental Matters, adopted in Aarhus, Denmark, in 1998.

2 Summary Report on the inventory of EU Member States' measures on access to justice in environmental matters, Millieu Ltd., 2007: (http://ec.europa.eu/environment/aarhus/study access.htm); How far has the EU applied the Aarhus Convention?, European Environmental Bureau, 2007: (http://www.eeb.org/activities/transparency/AARHUS FINAL-VERSION-WEBSITE-12-07.pdf); and Implementation of the Aarhus Convention in EU Member States, Justice \& Environment, 2006: (http://www.justiceandenvironment.org/wp-content/wpupload/JE2006Aarhuslegalanalysis.pdf).

3 More information about the conference can be found at: http://www.mzp.cz/en/event_aarhus_convention. ternational Visegrad Fund ${ }^{4}$ and Ministry for Housing, Spatial Planning and Environment of the Netherlands ${ }^{5}{ }^{6}$

\section{Standing conditions}

Specification of who shall have the right to ask for the court review acts or omissions concerning the environment and under what terms is evidently the key matter in terms of the application of the " $3^{\text {rd }}$ pillar" of the Aarhus Convention. With that regard, diverse approaches of the parties to defining the standing conditions, as well as the differences between paragraphs 2 and 3 of Art. 9 of the Convention should be mentioned. $^{7}$

\subsection{Impairment of right doctrine}

Basically, Art. 9(2) of the Convention aims to ensure that persons to whom the Art. 2(5) definition of "public concerned" 8 applies have the right to initiate the judicial review of acts and omissions related to permission of the projects subject to Art. 6 of the Convention. The parties may impose additional standing conditions, based either on the concept of "sufficient interest" or "impairment of rights".

Namely the latter one is interpreted very restrictively in some countries. In Austria, a general principle applies, according to which individual legal acts define specific rights, the violation of which (only and exclusively) can be claimed by a group of persons at court. For example, neighbours to a polluting facility may address air or water quality issues concerning their health or pollution of their private wells, but may not refer to general environmental considerations. Similar concepts are applied, for example, in Belgium, Germany, Malta and Slovenia. ${ }^{9}$ This approach does not take into account the possibility that the condition of

4 For more information see: http://www.visegradfund.org/.

5 For more information see: http://www.vrom.nl/.

6 Outcomes of these projects are published at http://www.justiceandenvironment.org/je-international/aarhus/.

7 Art. 9(1) ensures the possibility of judicial protection in cases that relate to access to environmental information, which is granted by Art. 4 of the Convention. This topic is not further discussed in this article.

8 "The public concerned" means the public affected or likely to be affected by, or having an interest in, the environmental decision-making; for the purposes of this definition, non-governmental organisations promoting environmental protection and meeting any requirements under national law shall be deemed to have an interest.

9 See also the Milleu Ltd. Summary Report on the inventory of EU Member States' measures on access to justice in environmental matters, supra note 2, p. 7. 
"impairment of rights" can also be fulfilled, for instance, regarding rights to protection of privacy, health or a favourable environment. At the same time, it does not seem to correspond to the objective of giving the "public concerned" wide access to justice within the scope of the Convention, expressed in Art. 9(2).

It is also characteristic for some countries which apply the strict version of "impairment of rights doctrine" (e.g. the Czech Republic) that the NGOs' access to justice in environmental matters is conditioned on their previous participation in administrative proceedings and limited on protection of their related procedural rights. This approach also affects the scope of their "permissible complaint arguments" (see section 3.2). ${ }^{10}$

Art. 9(3) of the Convention requires that "members of the public" (i.e. not necessarily the "public concerned") "when they meet the criteria, if any" have also access to review of acts or omissions with environmental concerns, to which Art. 6 does not apply. ${ }^{11}$ In these cases, the parties evidently have greater freedom in defining the limits of standing. However, the general principles expressed in the Preamble of the Convention and in its Articles 1 and 3 must also be respected in this case.

It can be said that neither legislation nor the judicial practice of most parties has dealt with the differences between the requirements of paragraphs 2 and 3 of Art. 9 so far. The Compliance Committee of the Aarhus Convention ${ }^{12}$ has, however, pointed out in its findings in the 2005/11 (Belgium) case, that the rationales of paragraphs 2 and 3 of Art. 9 of the Convention are apparently not identical. Subsequently, the Compliance Committee stressed that despite the Convention giving a great deal of flexibility in defining which subjects (namely environmental NGOs) have access to justice under Art. 9(3), the parties may not use the clause "where they meet the criteria, if any, laid down in its national law" as an excuse for introducing or maintaining criteria that is so strict that they effectively bar all or almost all environmental NGOs from challenging acts or omissions that contravene

10 Another alternative is the anchoring of detailed and difficult to fulfil terms, under which the NGOs can acquire a specific status, enabling them (in a specific scope) access to justice, such as, for instance, in Germany or Slovenia.

11 "In addition and without prejudice to the review procedures referred to in paragraphs 1 and 2 above, each Party shall ensure that, where they meet the criteria, if any, laid down in its national law, members of the public have access to administrative or judicial procedures to challenge acts and omissions by private persons and public authorities which contravene provisions of its national law relating to the environment.".

12 Compliance Committee of the convention is a body consisting of nine independent members, elected by the Meeting of the Parties, which was established in 2002 in accordance wit Art. 15 of the Convention. The main task of the Compliance Committee is to review if the Parties fulfil the requirements of the Convention, report the findings to the Meetings of the Parties and make recommendations. Most of the Compliance Committee activities are based on the individual complaints of the members of public. For more information see http://www.unece.org/env/pp/compliance.htm\#Documents national law relating to the environment. Access to such procedures should thus be the presumption, not the exception. ${ }^{13}$

\subsection{Broad interpretation of standing rights}

In some countries, though also their standing doctrines are generally based on the "impairment of rights", ratification of the Aarhus Convention resulted in a broadening the possibilities of access to courts in environmental matters. For instance, in Estonia the Supreme Administrative Court concluded that in environmental cases, the criterion of "impairment of rights" must be interpreted less restrictively in comparison to other areas, i.e. more in the sense of "affecting” a person by a specific act. Similarly, the Supreme Court in Hungary stated that the government's duty to harmonise legal orders with international obligations requires a more general interpretation of the terms of access to judicial protection. In contrast, in some cases concerning the environment, infringement of personal rights does not have to be proven at all.

On the basis of direct application of Art. 9(2) of the Convention, the Estonian courts also decided that the environmental NGOs shall have access to judicial protection without the need to prove violation of their rights and also without the need for special national legislation. They even acknowledged this right to groups (associations) without legal identity under the condition that they "represent the interests of a significant part of the local population". ${ }^{14}$ Also in Hungary, the Netherlands and Italy the NGOs do not need to prove infringement of their rights to get standing in environmental cases, as protection of "collective" or "diffuse interests" is considered as sufficient for their standing. ${ }^{15}$ Judicial interpretation of the term "affected interests" leads to the same situation in Great Britain or Ireland. ${ }^{16}$ Finally, when there is "actio popularis" anchored in the legal system (as in Portugal or Spain $)^{17}$, there is no doubt that the legislation is fully in compliance with the standing requirements of the Convention.

As Prof. Jerzy Jendroska pointed out at the conference, the provisions of the Convention took into ac-

13 See namely points 35 and 36 of the Compliance Committee findings and recommendations in the 2005/11 case.

14 See also the EEB study How far has the EU applied the Aarhus Convention?, supra note 2, p. 32.

15 See also the Milleu Ltd. Summary Report on the inventory of EU Member States' measures on access to justice in environmental matters, supra note 2, p. 8.

16 According to Lord Justice Robert Carnwath speech at the Conference, the courts in the common law countries mostly "welcome the expertise which the NGOs can bring to difficult cases raising technical issues".

17 In Spain "actio popularis" is always recognised for any of the criminal environmental offence included in the Criminal Code. In addition, "actio popularis" is also recognised at the administrative jurisdiction for the field of town planning and some other areas of environmental protection. However, "actio popularis" in criminal proceedings is significantly limited by deposits requested by courts from the plaintiffs. 
count different legal systems and traditions. At the same time, it attempts to reach a single standard of standing rights. Therefore, it directs the states requiring impairment as a general standing condition to consider any violation of the Convention's provisions (e.g. participation rights according to Art. 6) as "impairment of rights" with regard to the members of the public concerned.

\section{Scope of the review}

Delimitation of subjects authorised to access to justice in environmental matters is closely related to the scope of the judicial review of actions, proceedings and other legally important circumstances. This scope can be examined from two basic viewpoints:

- which actions and other circumstances can be subject to judicial review; and

- $\quad$ to what degree do the courts address the applied arguments.

\subsection{What is subject to review?}

With regard to the first question it is clear that in practice only those decisions or other circumstances, in relation to which it is possible for some subject to fulfil the conditions of standing, may be subject to judicial review. Therefore, if the legal order and/or practice of the courts of some country is or are based on the (strictly applied) doctrine of impairment of rights, the group of "reviewable" acts is thereby limited. For example, according to existing judicial interpretation in the Czech Republic, the affected persons cannot claim that a decision on permitting an exception from noise limits or approval for nuclear facilities to be put into operation to be reviewed. ${ }^{18}$ In the Netherlands, some decisions are expressly excluded from review with reference to the so-called "general rules for enterprises” replacing individual permits. ${ }^{19}$

\subsubsection{ElA statements}

Review of the results of environmental impact assessments (EIA) represents a specific problem. Where the final output of this process does not constitute a final decision (for instance an "EIA statement" in the Czech Republic or in Slovakia) the concept based on the requirement of proving infringement upon petitioner's rights leads to the conclusion that a (separate) judicial review of this act is not possible. ${ }^{20}$ Also in

18 Similarly, in Austria neither NGOs nor neighbours have (outside EIA and IPPC) access to justice in the following permitting procedures: railways, roads, shipping, nature conservation or most aspects of the water protection.

19 See also the Milleu Ltd. Summary Report on the inventory of EU Member States' measures on access to justice in environmental matters, supra note 2, p. 7.

20 A participant at the Conference questioned whether the Czech Supreme Administrative Court acted correctly when it refused to file a preliminary question to the ECJ concerning the direct review of the EIA statement (regarding the timeliness and efficiency of judicial review of the EIA procedure).
Spain, difficulties were encountered with regard to the review of the administrative appeals against decisions on EIA screening, as these decisions have so far been understood as merely procedural acts.

On the contrary in Estonia the Supreme Court stated, that "even though procedural decisions are generally not subject to judicial review, it is necessary to proceed differently in cases concerning encroachment upon the environment, because in these cases procedural aspects have a fundamental impact on the final result of decision making”.

\subsubsection{Land use plans}

Another specific area is the review of land use plans. The contentious matter here is whether or under what circumstances the plan can be regarded as a decision in terms of the permission of a specific activity in accordance with Art. 6 of the Convention. Also the question is whether the provisions on access to judicial protection according to Art. 9(2) of the Convention apply. According to the findings of the Compliance Committee in the 2005/11 (Belgium) case, the town plans can be regarded as a permitting decision if they are sufficiently specific.

\subsubsection{Acts and omissions of private persons}

Application of the principle of "impairment of rights" also restricts access to the review of actions and omissions by private persons, if these actions do not have direct and immediate consequences on the personal rights of the plaintiff, but rather on the environment as a public interest. An example of progressive legislation with regard to the judicial review of actions by private subjects is the Polish Environmental Protection Act, according to which NGOs may file an action in cases where the threat or violation affects the environment as a common good.

\subsection{What can be objected?}

With regard to the issue of "permissible complaint arguments" or the scope in which the courts deal with individual acts, the situation is again problematic in countries where a strictly interpreted doctrine of the impairment of rights is applied. For instance, according to Austrian legislation the affected individuals (e.g. landowners) may only ask for a review of infringement based on their ownership rights and rights to protection of health. They cannot object to violation of other provisions of environmental laws. This significantly restricts the scope of judicial review of official decisions.

Concerning actions by non-government organisations, the Czech courts have declared that permissible complaint objections are only those that concern infringement of the procedural rights of these petitioners during proceedings before administrative offices. However, the actual method of application of this principle differs greatly in individual cases (in some it is very 
strict, ${ }^{21}$ in others the courts address substantive objections either "by means" of the review of the right to due settlement of objections, or without any theoretical justification). In practice, the formal insistence of courts on this concept leads to a differing and unbalanced scope of review in similar cases. The whole concept is, according to my assessment, based on a confusion of the terms of standing (where it can be in compliance with the Aarhus Convention to limit the scope of persons with access to courts by the requirement of impairment of rights) and the scope of review of the challenged decision. Regarding the latter, Art. 9(2) of the Convention clearly indicates that members of public can challenge both procedural and substantive legality of the decision.

In contrast to this approach, it can be pointed out that in a number of other states the issue of the scope of the review (if this concerns a review of the legality of the decision) is not a problematic matter at all - it is accepted that the petitioner may apply any arguments in this direction. Often the Hungarian courts, for example, not only review the substantive legality of an administrative decision (e.g. whether the limit values for pollutions are applied correctly), but also the scientific correctness of the supporting technical documentation, most notably the environmental impact statement.

\section{Effectiveness of judicial protection}

Access to justice in environmental matters only really makes sense if there is a literal possibility of preventing encroachment upon the environment by its means. Art. 9(4) of the Arhus Convention therefore expressly specifies the duty of the parties to secure the opportunity of achieving preliminary measures, including injunctive relief. It was stressed a couple of times at the Conference that the Convention requires injunctive relief and other remedies to be "adequate and effective”. Adequacy requires that the measures can fully compensate past damage or at least prevent future damage. The requirement that the remedies should be effective means that they should be capable of efficient enforcement. Parties should try to eliminate any potential barriers to the enforcement of injunctions and other remedies.

Practice of lengthy court proceedings in combination with restricted or wholly excluded option of achieving an injunctive relief, which leads to "academic victories" (cancelling the permits for already executed projects), is in conflict with these requirements of the Convention. The legislation and until recently also court practice in the Czech Republic represented such

21 In one of the cases the court dismissed the consideration of arguments that the project was not assessed in the EIA procedure, although it should have been, and that the impact of the project on the Natura 2000 area was evaluated wrongly, as these objections are not related to the plaintiff's procedural rights. a combination. However, in several of its recent judgments, the Czech Supreme Administrative Court expressed the legal opinion that in spite of the strict legislative terms for acknowledgement of the suspensive effect of the action (i.e. requirement of the petitioner being at risk of "irrecoverable harm") the courts shall acknowledge a suspensive effect to complaints by members of the public concerned in cases that are subject to the Aarhus Convention. In Spain, the application of injunctive relief is significantly limited by usual settlement of unaffordable bails by the courts; there are, however, individual cases in which the courts decided not to impose the bail or to reduce it to allow access to justice on the grounds of the Aarhus Convention requirements.

The practice in some other countries is more accommodated to the preliminary protection against irrecoverable encroachment of the environment, and thus more compatible with the requirements of the Convention. For instance, the Estonian law requires evaluation of whether the fulfilment of court decision would become impossible if suspensive effect would not be awarded to a complaint. This provision was interpreted by the Supreme Court in a way that starting construction works in a protected area would create irreversible consequences (because demolition of already constructed buildings is not reasonable). Apart from this, Estonian courts may issue various types of preliminary measures - for instance forbid offices to issue subsequent decisions or suspend running activities. Risk of serious damage to the environment represents an important aspect of the decisions if the suspensive effect is also to be awarded to a complaint in Hungary, Slovenia and Belgium (here also expressly in relation to non-government organisations). ${ }^{22}$

In relation to the judicial review of actions by private individuals, achieving preliminary measures is generally more difficult and frequently related to the requirement of depositing a guarantee in case of subsequent disputes on compensation of damages. In $\mathrm{Po}_{\mathrm{o}}$ land, however, the law enables the courts to impose preventive measures, in particular by putting in place an installation or equipment to protect against the threat or damage. Where taking such measures is impossible or too difficult, the court may impose ceasing the activity causing the threat. $^{23}$

22 See also the Milleu Ltd. Summary Report on the inventory of EU Member States' measures on access to justice in environmental matters, supra note 2, p. 13.

23 At the Conference working group, the opinion prevailed that it is not contrary to the Convention if members of the affected public cannot challenge omissions of the authorities to stop illegal activities on the basis of administrative law when they can challenge these illegal activities directly (on the basis of civil law) at the same time. However, this can be seen as an academic concept, as civil lawsuits against private persons often require high costs and it is up to the plaintiff to carry the burden of proof. As a result, civil law on its own usually does not provide for effective remedies in environmental matters. 


\section{Additional remarks}

The list provided of problematic matters concerning application of Art. 9 of the Aarhus Convention in individual states is certainly not exhaustive. For instance, the barrier of access to court because of the high costs of proceedings and risk of having to pay compensation in the event of losing a case was mentioned only briefly, although it represents a fundamental problem in some states. ${ }^{24}$

Next to concrete problems of this kind, some more general aspects influencing the implementation of the Convention by the parties were discussed at the Conference, namely the matter of overall position of the Convention in the national legal systems (the question of its direct applicability). It is evident form the above-mentioned examples that in some countries the courts have acceded to the direct application of the Convention while in others it has been refused. Prof. Luc Lavrysen has pointed out that the question of direct applicability must be solved individually for every single provision. It was pointed out, that the Compliance Committee repeatedly stated that (some) provisions of the Aarhus Convention should be directly applicable by the parties. ${ }^{25}$ It was also emphasised that regardless of the issue of whether the Convention is "capable of direct application", the courts should always interpret the relevant national provisions in accordance with the requirements of the Convention. A specific and very complex variant of this issue is the question of the Convention's position on inferential consequences and EC law. The EU has ratified the Convention by the Council Decision 2005/370/EC from 17 February 2005. In this way, the Convention has become, as a so-called "mixed agreement", ${ }^{26}$ part of EC law. It was discussed at the Conference what this means for the enforcement of the Convention requirements (namely according to Art. 9) by EC institutions on the Member State level. A number of the participants criticised the fact that the proposal of the directive on access to justice in environmental matters - which would implement the requirements of Art. 9(3) of the Convention into the EC law in detail - has not been approved. ${ }^{27}$

It was also discussed whether the approach of the ECJ to the issue of standing of environmental NGOs and other members of public concerned before this $\operatorname{court}^{28}$,

24 See for example the Milleu Ltd. Summary Report on the inventory of EU Member States' measures on access to justice in environmental matters, supra note 2, pp. 13-16.

25 See the findings in the 2006/17 (European Community) case, points 59-61, or findings in the 11/2005 (Belgium) case, point 16.

26 See for example R. Leal-Arcas, The European Community and Mixed Agreements, European Foreign Affairs Review 6, 483-613 (2001).

27 See http://ec.europa.eu/environment/aarhus/index.htm\#justice for more information.

28 For details see for example the communication to the Compliance Committee by ClientEarth, Belgium, concerning the alleged non-conformity of the which has so far been very restrictive, could be changed in the light of the ratification of the Aarhus Convention by the EC, and subsequent adoption of the $1367 / 2006$ "Aarhus Regulation”. ${ }^{29}$ Dealing with this issue in greater detail unfortunately lies outside the scope of this article.

\section{Conclusions}

The examples presented in this article show that it is possible to interpret Art. 9 of the Aarhus Convention in a variety of ways with regard to terms for access to judicial protection in environmental matters. The restrictive attitude of national courts on this issue, based on the "impairment of right doctrine", limits the scope of cases in which legal steps can lead to effective protection of the environment. The same doctrine can be interpreted in a way that leads to broad and relatively efficient access to justice. The approach of, for example, the Estonian or Hungarian Supreme courts to the standing of NGOs, the scope of the judicial review as well as the possibility of preliminary measures (suspensive effects of the lawsuits), influenced by the direct application of the provisions of the Convention, demonstrates this. Also the Polish Environmental Protection Act, according to which NGOs can take legal action in cases of risk or damage of the environment as "common welfare", is an example of a good implementation of the Aarhus Convention principles.

Such approaches are consistent with the opinion presented at the Conference by Lord Justice Robert Carnwath. According to him, if the legislative and administrative instruments of protection of the environment are not developed sufficiently or do not work properly, the courts and judges shall "fill the gaps", namely by "creative interpretation of the constitutional laws". This shall be an integral part of their task to promote efficient and fair enforcement of the principles and standards anchored in laws, as well as individual rights, even if it would be in conflict with political preferences of the majority.

To perform this role successfully, the courts need a sufficient number of active individuals and groups who are willing to "carry on the risks" of participation in the legal processes. The Aarhus Convention, if interpreted and used properly, can be seen as a tool for limiting these risks and enhancing the position of the members of the public actively involved in the environmental protection.

European Communities with the requirements of Art. 9 of the Aarhus Convention (available at http://www.unece.org/env/pp/compliance/C200832/communication/Communication.pdf).

29 Regulation on the application of the provisions of the Aarhus Convention on Access to Information, Public Participation in Decision-making and Access to Justice in Environmental Matters to Community institutions and bodies. 


\section{Imprint}

Editors: Hendrik Acker, Regine Barth, Nicola Below, Martin Führ, Gerhard Roller

Editors in charge of the current issue: Martin Führ and Nicola Below

Editor in charge of the forthcoming issue: Gerhard Roller (roller@fh-bingen.de)

The Editors would like to thank Vanessa Cook (Öko-Institut) for proofreading the elni Review.

Manuscripts should be submitted as files by email to the Editors using an IBM-compatible word processing system.
The elni Review is the double-blind peer reviewed journal of the Environmental Law Network International. It is distributed twice a year at the following prices: commercial users (consultants, law firms, government administrations): $€ 52$; private users, students, libraries: $€ 30$. Non-members can order single issues at a fee of $€ 20$ incl. packaging. The Environmental Law Network International also welcomes an exchange of articles as a way of payment.

The elni Review is published with financial and organisational support from Öko-Institut e.V., and the Universities of Applied Sciences in Darmstadt and Bingen.

The views expressed in the articles are those of the authors and do not necessarily reflect those of elni.

\section{Authors of this issue}

Marta Ballesteros, Lawyer specialising in European Law and Institutions at the University of Louvain-la-Neuve, Belgium. She works as a Senior Lawyer on climate and energy issues at ClientEarth in Brussels, and is also Executive Secretary at Ecosphere in Brussels, mballesteros@clientearth.org

Ana Barreira, Lawyer, LL.M London University and LL.M New York University, Director of Instituto Internacional de Derecho y Medio Ambiente (IIDMA) in Spain, and is also a member of the IUCN Commission on Environmental Law, ana.barreira@iidma.org

Nicola Below, Lawyer specialising in IP, IT and information law. He is a research assistant at the Society for Institutional Analysis (sofia), University of Applied Sciences in Darmstadt, Germany, below@sofia-darmstadt.de

Michael Benske, Lawyer specialising in IP, IT and e-commerce law. He is a former trainee at the Delegation of the European Commission in Beijing, China, and has worked on Sino-European intellectual property law issues and strategies, michael@benske.de
Julien Bétaille, PhD candidate and lecturer at the Interdisciplinary Centre of Research in Environmental, Urban and Planning Law (CRIDEAUOMIJ EA 3177) at the University of Limoges, France, julien.betaille@unilim.fr

Pavel Černý, Lawyer working for Environmental Law Service (ELS) in Brno, the Czech Republic and for the Justice \& Environment Association, pavel.cerny@eps.cz

Marie-Catharine van Engelen, Lawyer at Pels Rijcken \& Droogleever Fortuijn in the practice group European and Competition Law, at The Hague, The Netherlands,

mc.vanengelen@pelsrijcken.nl

Lesley James, Specialist for industrial management and power plants, and a Campaigner on Acid Rain at Friends of the Earth (FoE - England, Wales \& Northern Ireland). She also works on the European Commission's IPPC Review Advisory Group, Hayfield, United Kingdom, lesley.james@foe.co.uk

Christian Schaible, Lawyer specialised in environmental law, and is EU Policy Officer for Industrial Policies and Chemicals at the European Environmental Bureau (EEB) in Brussels, Belgium, christian.schaible@eeb.org 


\section{elni membership}

If you want to join the Environmental Law Network International, please use the membership form on our website: http://www.elni.org or send this form to the elni Coordinating Bureau, c/o IESAR, FH Bingen, Berlinstr. 109, 55411 Bingen, Germany, fax: +49-6721-409 110, mail: Roller@fh-bingen.de.

The membership fee is $€ 52$ per year for commercial users (consultants, law firms, government administration) and $€ 21$ per year for private users and libraries. The fee includes the bi-annual elni Review. Reduced membership fees will be considered on request.

Please transfer the amount to our account at Nassauische Sparkasse - Account no.: 146060 611, BLZ 510 500 15, IBAN: DE50 5105001501460606 11; SWIFT NASSDE55XXX.

"Yes, I hereby wish to join the Environmental Law Network International."

Name:

Organisation:

Profession:

Street:

City:

Country:

Email:

Date: 
The Öko-Institut (Institut für angewandte Ökologie - Institute for Applied Ecology, a registered nonprofit-association) was founded in 1977. Its founding was closely connected to the conflict over the building of the nuclear power plant in Wyhl (on the Rhine near the city of Freiburg, the seat of the Institute). The objective of the Institute was and is environmental research independent of government and industry, for the benefit of society. The results of our research are made available of the public.

The institute's mission is to analyse and evaluate current and future environmental problems, to point out risks, and to develop and implement problem-solving strategies and measures. In doing so, the ÖkoInstitut follows the guiding principle of sustainable development.

The institute's activities are organized in Divisions - Chemistry, Energy \& Climate Protection, Genetic Engineering, Sustainable Products \& Material Flows, Nuclear Engineering \& Plant Safety, and Environmental Law.

\section{The Environmental Law Division of the Öko-Institut:}

The Environmental Law Division covers a broad spectrum of environmental law elaborating scientific studies for public and private clients, consulting governments and public authorities, participating in law drafting processes and mediating stakeholder dialogues. Lawyers of the Division work on international, EU and national environmental law, concentrating on waste management, emission control, energy and climate protection, nuclear, aviation and planning law.

Contact

Freiburg Head Office:

P.O. Box 500240

D-79028 Freiburg

Phone +49 (0)761-4 52 95-0

Fax +49 (0)761-4 529588

Darmstadt Office:

Rheinstrasse 95

D-64295 Darmstadt

Phone +49 (0)6151-81 91-0

Fax +49 (0)6151-819133

Berlin Office:

Novalisstrasse 10

D-10115 Berlin

Phone +49(0)30-280 48680

Fax +49(0)30-280 48688

www.oeko.de

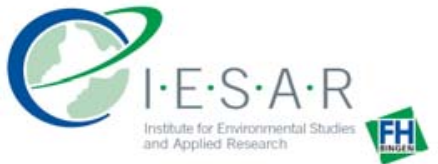

The University of Applied Sciences in Bingen was founded in 1897. It is a practiceorientated academic institution and runs courses in electrical engineering, computer science for engineering, mechanical engineering, business management for engineering, process engineering, biotechnology, agriculture, international agricultural trade and in environmental engineering.

The Institute for Environmental Studies and Applied Research (I.E.S.A.R.) was founded in 2003 as an integrated institution of the University of Applied Sciences of Bingen. I.E.S.A.R carries out applied research projects and advisory services mainly in the areas of environmental law and economy, environmental management and international cooperation for development at the University of Applied Sciences and presents itself as an interdisciplinary institution.

The Institute fulfils its assignments particularly by:

- Undertaking projects in developing countries

- Realization of seminars in the areas of environment and development

- Research for European Institutions

- Advisory service for companies and know-how-transfer

Main areas of research:

- European environmental policy

o Research on implementation of European law

o Effectiveness of legal and economic instruments

o European governance

- Environmental advice in developing countries

o Advice for legislation and institution development

o Know-how-transfer

- Companies and environment o Environmental management o Risk management

Contact

Prof. Dr. jur. Gerhard Roller

University of Applied Sciences

Berlinstrasse 109

D-55411 Bingen/Germany

Phone +49(0)6721-409-363

Fax +49(0)6721-409-110

roller@fh-bingen.de

www.fh-bingen.de
The Society for Institutional Analysis was established in 1998. It is located at the University of Applied Sciences in Darmstadt and the University of Göttingen, both Germany.

The sofia research group aims to support regulatory choice at every level of public legislative bodies (EC, national or regional). It also analyses and improves the strategy of public and private organizations.

The sofia team is multidisciplinary: Lawyers and economists are collaborating with engineers as well as social and natural scientists. The theoretical basis is the interdisciplinary behaviour model of homo oeconomicus institutionalis, considering the formal (e.g. laws and contracts) and informal (e.g. rules of fairness) institutional context of individual behaviour.

The areas of research cover

- Product policy/REACh

- Land use strategies

- Role of standardization bodies

- Biodiversity and nature conversation

- Water and energy management

- Electronic public participation

- Economic opportunities deriving from environmental legislation

- Self responsibility

sofia is working on behalf of the

- VolkswagenStiftung

- German Federal Ministry of Education and Research

- Hessian Ministry of Economics

- German Institute for Standardization (DIN)

- German Federal Environmental Agency (UBA)

- German Federal Agency for Nature Conservation (BfN)

- Federal Ministry of Consumer Protection, Food and Agriculture

\section{Contact}

Darmstadt Office

Prof. Dr. Martin Führ - sofia

University of Applied Sciences

Haardtring 100

D-64295 Darmstadt/Germany

Phone +49(0)6151-16-8734/35/31

Fax +49(0)6151-16-8925

fuehr@sofia-darmstadt.de www.h-da.de

Göttingen Office

Prof. Dr. Kilian Bizer - sofia

University of Göttingen

Platz der Göttinger Sieben 3

D-37073 Göttingen/Germany

Phone +49(0)551-39-4602

Fax +49(0)551-39-19558

bizer@sofia-darmstadt.de 
In many countries lawyers are working on aspects of environmental law, often as part of environmental initiatives and organisations or as legislators. However, they generally have limited contact with other lawyers abroad, in spite of the fact that such contact and communication is vital for the successful and effective implementation of environmental law.

\section{Therefore, a group of} lawyers from various countries decided to initiate the Environmental Law Network International (elni) in 1990 to promote international communication and cooperation worldwide. Since then, elni has grown to a network of about 350 individuals and organisations from all over the world.

Since 2005 elni is a registered non-profit association under German Law.

\section{elni coordinates a number} of different activities in order to facilitate the communication and connections of those interested in environmental law around the world.

\section{Coordinating Bureau}

The Coordinating Bureau was originally set up at and financed by ÖkoInstitut in Darmstadt, Germany, a non-governmental, non-profit research institute.

Three organisations currently share the organisational work of the network: Öko-Institut, IESAR at the University of Applied Sciences in Bingen and sofia, the Society for Institutional Analysis, located at the University of Darmstadt. The person of contact is Prof. Dr. Roller at IESAR, Bingen.

\section{elni Review}

The elni Review is a bi-annual, English language law review. It publishes articles on environmental law, focussing on European and international environmental law as well as recent developments in the EU Member States. It is published by Öko-Institut (the Institute for Applied Ecology), IESAR (the Institute for Environmental Studies and Applied Research, hosted by the University of Applied Sciences in Bingen) and sofia (the Society for Institutional Analysis, located at the University of Darmstadt). The Coordinating Bureau is currently hosted by the University of Bingen. elni encourages its members to submit articles to the Review in order to support and further the exchange and sharing of experiences with other members.

\section{elni Conferences and Fora}

elni conferences and fora are a core element of the network. They provide scientific input and the possibility for discussion on a relevant subject of environmental law and policy for international experts. The aim is to gather together scientists, policy makers and young researches, providing them with the opportunity to exchange views and information as well as to develop new perspectives.

The aim of the elni fora initiative is to bring together, on a convivial basis and in a seminar-sized group, environmental lawyers living or working in the Brussels area, who are interested in sharing and discussing views on specific topics related to environmental law and policies.

\section{Publications series}

- Access to justice in Environmental Matters and the Role of NGOs, de Sadeleer/Roller/Dross, Europa Law Publishing, 2005.

- Environmental Law Principles in Practice, Sheridan/Lavrysen (eds.), Bruylant, 2002.

- Voluntary Agreements - The Role of Environmental Agreements, elni (ed.), Cameron May Ltd., London, 1998.

- Environmental Impact Assessment European and Comparative; Law and Practical Experience, elni (ed.), Cameron May Ltd., London, 1997.

- Environmental Rights: Law, Litigation and Access to Justice, Deimann/ Dyssli (eds.), Cameron May Ltd., London, 1995.

- Environmental Control of Products and Substances: Legal Concepts in Europe and the United States, Gebers/Jendroska (eds.), Peter Lang, 1994.

- Dynamic International Regimes: Institutions of International Environmental Governance, Thomas Gehring; Peter Lang, 1994.

- Environmentally Sound Waste Management? Current Legal Situation and Practical Experience in Europe, Sander/Küppers (eds.), P. Lang, 1993

- Licensing Procedures for Industria Plants and the Influence of EC Directives, Gebers/Robensin (eds.), P. Lang, 1993.

- Civil Liability for Waste, v. Wilmowsky/Roller, P. Lang, 1992.

- Participation and Litigation Rights of Environmental Associations in Europe, Führ/Roller (eds.), P. Lang, 1991.

\section{Elni Website: elni.org}

On the elni website www.elni.org one finds news of the network and an index of articles. It also indicates elni activities and informs about new publications. Internship possibilities are also published online. 